DOI: https://doi.org/10.24127/ajpm.v10i3.3912

\title{
PENGEMBANGAN MEDIA PEMBELAJARAN MATEMATIKA BERBASIS ANDROID BERBANTUAN SMART APPS CREATOR DALAM MENINGKATKAN KEMAMPUAN PEMECAHAN MASALAH
}

\author{
Isnaini Mahuda ${ }^{*}$, Ranny Meilisa ${ }^{2}$, Anton Nasrullah ${ }^{3}$ \\ ${ }^{1 *}$ Matematika, Universitas Bina Bangsa, Serang, Indonesia \\ ${ }^{2}$ Pendidikan Teknologi Informasi, Universitas Bina Bangsa, Serang, Indonesia \\ ${ }^{3}$ Pendidikan Matematika, Universitas Bina Bangsa, Serang, Indonesia \\ *Corresponding author. \\ E-mail: $\quad \frac{\text { isnaini.mahuda@binabangsa.ac.id }{ }^{\left.I^{2}\right)}}{\frac{\text { ranny.meilisa@binabangsa.ac.id }}{\left.{ }^{2}\right)}}$
}

Received 04 July 2021; Received in revised form 13 September 2021; Accepted 28 September 2021

\begin{abstract}
Abstrak
Penelitian ini bertujuan untuk: a) menguji validitas media pembelajaran matematika berbasis Android berbantuan Smart Apps Creator menurut para ahli materi dan media; b) menguji tingkat kepraktisan media pembelajaran matematika berbasis Android berbantuan Smart Apps Creator menurut mahasiswa pengguna; dan c) menguji tingkat efektivitas media pembelajaran matematika berbasis Android berbantuan Smart Apps Creator terhadap peningkatan kemampuan penguasaaan pemecahan masalah matematis mahasiswa pengguna. Subjek penelitian adalah mahasiswa semester dua yang mengambil matakuliah matematika ekonomi di salah satu perguruan tinggi di Banten. Instrumen yang digunakan adalah angket dan tes. Penelitian ini menggunakan jenis penelitian dan pengembangan atau yang dikenal dengan Research and Development (R\&D) dengan model pengembangan ADDIE terdiri dari 5 (lima) tahapan yaitu Analysis, Design, Development, Implementation, dan Evaluation. Hasil uji kevalidan dari para ahli materi dan media diperoleh bahwa media pembelajaran matematika berbasis android berbantuan Smart Apps Creator termasuk pada kriteria kelayakan sangat valid dan dapat digunakan tanpa revisi. Uji kepraktisan oleh mahasiswa pengguna media pembelajaran diperoleh bahwa media pembelajaran matematika berbasis android berbantuan Smart Apps Creator termasuk dalam kriteria sangat praktis. Adapun uji efektivas produk yang dikembangkan diperoleh bahwa media pembelajaran matematika berbasis android berbantuan Smart Apps Creator efektif dalam meningkatkan kemampuan pemecahan masalah matematis.
\end{abstract}

Kata kunci: Android; kemampuan pemecahan masalah; media pembelajaran; Smart Apps Creator.

\begin{abstract}
This study aims to: a) test the validity of the Android-based mathematics learning media assisted by Smart Apps Creator according to material and media experts; $b$ ) testing the practicality of the Android-based math learning media assisted by Smart Apps Creator according to student users; c) testing the effectiveness of the Android-based mathematics learning media assisted by Smart Apps Creator towards increasing the students' mathematical problem-solving ability. The research subjects were second-semester students who took economics mathematics courses at one of the universities in Banten. The instruments used are questionnaires and tests. This study uses a type of research and development known as Research and Development $(R \& D)$ with the ADDIE development model consisting of 5 (five) stages, namely Analysis, Design, Development, Implementation, and Evaluation. The validity test results from material and media experts showed that the Android-based mathematics learning media assisted by Smart Apps Creator included very valid criteria and could be used without revision. The practicality test by students using learning media obtained that the Android-based mathematics learning media assisted by Smart Apps Creator was included in the very practical criteria. As for the product effect test, it was obtained that the Android-based mathematics learning media assisted by Smart Apps Creator was effective in improving students' problem-solving skills.
\end{abstract}

Keywords: Android; learning media; problem-solving ability; Smart Apps Creator.

This is an open access article under the Creative Commons Attribution 4.0 International License 
DOI: https://doi.org/10.24127/ajpm.v10i3.3912

\section{PENDAHULUAN}

Pembelajaran online dan pemanfaatan teknologi merupakan dua hal yang tidak dapat dipisahkan di masa pandemi Covid-19. Tidak mungkin pembelajaran online dapat dilakukan tanpa memanfaatkan teknologi yang ada. Tatap muka di dalam kelas kini digantikan dengan tatap muka virtual di ruang virtual, membutuhkan perangkat teknologi seperti komputer/laptop atau smartphone yang terhubung melalui internet. Setiap pendidik dalam hal ini guru atau dosen harus mengemas bahan ajar pembelajaran online secara menarik dan inovatif agar tujuan pembelajaran tetap dapat tercapai secara optimal.

Berdasarkan evaluasi pelaksanaan pembelajaran online beberapa semester sebelumnya, dosen memberikan bahan ajar berupa modul dalam bentuk PDF atau PowerPoint, yang kemudian diberikan kepada mahasiswa melalui WhatsApp Group, Google Classroom, Edmodo dan aplikasi lainnya. Penyajian bahan ajar dalam bentuk ini mendapat tanggapan dari siswa seperti kurang menarik, monoton, dan kurang mampu memanfaatkan teknologi yang lebih canggih. Atas dasar itu, diperlukan media pembelajaran digital dengan memanfaatkan teknologi yang berkembang pesat saat ini, seperti smartphone berbasis Android (Putra, Sudiana, \& Pamungkas, 2020).

Penggunaan smartphone yang dilengkapi dengan berbasis Android semakin berkembang, dan terbukti hingga pertengahan tahun 2020, Android menjadi sistem operasi mobile yang paling mendominasi di dunia. Di Indonesia sendiri, sebanyak 250 juta orang memungkinkan sebagian penduduk menjadi pengguna aktif smartphone (Putra et al., 2020). Smartphone berbasis Android telah menjadi kebutuhan primer dalam kehidupan manusia akhir-akhir ini. Android merupakan salah satu sistem operasi mobile yang pertumbu-hannya relatif cepat dan pesat di antara sistem operasi lain yang sedang berkembang saat ini. Android sebagai sistem operasi untuk smartphone digambarkan sebagai jembatan antara perangkat (device) dan penggunaannya untuk berinteraksi dengan perangkat mereka dan menjalankan aplikasi yang tersedia pada perangkat tersebut (Dasmo, Astuti, \& Nurullaeli, 2017).

Saat ini hampir semua pelajar atau generasi milenial pasti memiliki smartphone berbasis Android. Media pembelajaran dengan memanfaatkan smartphone berbasis android dapat dirancang agar proses pembelajaran dapat dilakukan kapan saja dan dimana saja atau dikenal dengan istilah mobile learning. Penggunaan mobile learning dapat menunjang proses belajar mengajar dan menambah keleluasaan dalam kegiatan belajar mengajar sehingga hasil belajar menjadi lebih baik (Robianto, Wahono, \& Marsono, 2019).

Salah satu aplikasi yang dapat membuat media pembelajaran berbasis android adalah Smart Apps Creator atau disingkat SAC. SAC adalah media interaktif digital terbaru yang membangun konten multimedia yang dapat diinstal pada smartphone berbasis Android (Suhartati, 2021). Pembuatan aplikasi mobile multimedia pembelajaran dengan SAC dapat dilakukan karena tidak memerlukan kode pemrograman dan dapat menghasilkan format HTML5 dan .exe. SAC dapat digunakan untuk mengembangkan aplikasi mobile learning, mobile quiz, mobile tourism/tourism, mobile company profile, mobile product profile, mobile city branding, mobile marketing, dan masih banyak lainnya (Azizah, 2020). SAC sebagai software 
DOI: https://doi.org/10.24127/ajpm.v10i3.3912

memiliki beberapa keunggulan diantaranya; 1) tidak memerlukan keahlian pemrograman sehingga siapapun dapat mengoperasikannya secara efisien, 2) Output dari aplikasi ini dapat diimplementasikan pada berbagai platform salah satunya pada Android, 3) Dapat menyisipkan animasi sesuai dengan kebutuhan dan keinginan pengembang, 4) interaktivitas, 5) Mendukung berbagai jenis format untuk media penyimpanan, dan 6) layanan web terintegrasi sehingga aplikasi menjadi lebih fungsional (Budyastomo, 2020).

Media pembelajaran berbasis android dapat dikembangkan dalam proses pembelajaran matematika untuk memudahkan siswa dalam menunjang keberhasilan belajarnya dan meningkatkan kemampuan pemecahan masalah matematis siswa khususnya di tengah pembelajaran online saat ini. Aplikasi Android yang disertai dengan video, audio, animasi dengan teks dan gambar dapat meningkatkan pengalaman, pemahaman, minat dan perhatian siswa terhadap materi (Chang, Liang, Chou, \& Lin, 2017). Hasil penelitian menyatakan bahwa model pembelajaran berbantuan perangkat pembelajaran matematika berbasis android dapat meningkatkan daya tarik dan kemampuan pemecahan masalah (Qurohman, Sungkar, \& Abidin, 2019).

Berdasarkan pemaparan di atas maka tertarik untuk mengembangkan media pembelajaran matematika berbasis Android berbantuan Smart Apps Creator dalam upaya meningkatkan kemampuan pemecahan masalah matematis mahasiswa. Adapun tujuan dari penelitian ini adalah untuk: a) menguji validitas media pembelajaran matematika berbasis Android berbantuan Smart Apps Creator menurut para ahli materi dan media; b) menguji tingkat kepraktisan media pembelajaran matematika berbasis Android berbantuan Smart Apps Creator menurut mahasiswa pengguna; dan c) menguji tingkat efektivitas media pembelajaran matematika berbasis Android berbantuan Smart Apps Creator terhadap peningkatan kemampuan penguasaaan pemecahan masalah matematis mahasiswa pengguna.

\section{METODE PENELITIAN}

Penelitian ini menggunakan jenis penelitian dan pengembangan atau yang dikenal dengan Research and Development (R\&D). Dalam penelitian ini digunakan model pengembangan yaitu model ADDIE. Model ADDIE merupakan model penelitian dan pengembangan yang terdiri dari 5 (lima) tahapan yaitu Analysis, Design, Development, Implementation, dan Evaluation. Kelima tahapan tersebut harus dilakukan secara terstruktur dan berkesinambungan.

Pada tahapan analysis meliputi analisis media, analisis kurikulum dan analisis materi. Analisis media dilakukan untuk mengetahui sejauh mana pemanfaatan media yang akan dikembangkan dalam pembelajaran. Dalam melakukan analisis media menggunakan studi pustaka yang berkaitan tentang aspek yang harus terkandung dalam media. Analisis kurikulum dilakukan dengan mengkaji kurikulum yang sedang diterapkan agar media pembelajaran dikembangkan sesuai dengan kurikulum yang berlaku. Kajian terhadap kurikulum diantaranya meliputi kompetensi inti, kompetensi dasar, dan indikator yang harus dicapai. Analisis materi dilakukan untuk menentukan materi yang akan dipelajari dalam pembelajaran menggunakan media yang dikembangkan.

Pada tahap design bertujuan untuk menghasilkan suatu produk awal 
(prototype) atau rancangan produk yang disesuaikan dengan analisis yang telah dilakukan. Adapun kegiatan yang dilakukan pada tahap ini yaitu pemilihan format dan kerangka awal serta pemilihan instrument. Selanjutnya yaitu tahap development sebagai kelanjutan dari tahap design maka pada tahap ini mulai dilakukan pengembangan rancangan media pembelajaran yang telah dibuat. Pada tahap development ini terdiri dari beberapa langkah diantaranya yaitu: a) mengembangkan rancangan kerangka media pembelajaran dan instrumen yang dibuat pada tahap sebelumnya, yang selanjutnya akan dievaluasi oleh para ahli, b) Penilaian terhadap media pembelajaran yang dilakukan oleh para ahli yang berkompeten di bidang media dan materi serta mampu memberikan kritik dan saran agar penyusunan media menjadi lebih baik, dan c) melakukan revisi atas media yang telah divalidasi berdasarkan saran serta kritik dari para ahli media dan materi.

Tahap Implementation yaitu media pembelajaran yang telah dikembangkan dan dinyatakan layak uji oleh dosen ahli media dan ahli materi selanjutnya diujicobakan kepada subyek penelitian dalam skala kecil. Pada tahap ini dilakukan pretest-posttest untuk mengukur keefektifan peningkatan kemampuan pemecahan masalah sebelum dan sesudah penggunaan media.

Terakhir yaitu tahap Evaluation dilakukan revisi akhir terhadap media pembelajaran yang dikembangkan berdasarkan angket dan lembar observasi yang diperoleh di lapangan.

Adapun subyek dari penelitian dan pengembangan ini adalah mahasiswa semester II tahun akademik 2020/2021 jurusan Manajemen Fakultas Ekonomi dan Bisnis Universitas Bina Bangsa yang berjumlah 35 orang. Objek pada penelitian dan pengembangan ini adalah modul berbasis aplikasi android berbantuan Smart Apps Creator untuk mata kuliah Matematika Ekonomi.

Teknik pengumpulan data yang digunakan pada penelitian ini adalah: (1) Lembar validasi, yang diserahkan kepada ahli media dan ahli materi untuk mendapatkan komentar, saran ataupun kritik sebagai dasar revisi produk untuk menentukan kelayakan produk. (2) Lembar angket tanggapan mahasiswa, yang diserahkan kepada mahasisswa pengguna media sebagai subyek penelitian untuk mengetahui sejauh mana respon mahasiswa terhadap media pembelajaran yang dikembangkan. (3) Instrumen tes yaitu pretes dan postes yang disusun berdasarkan indikator kemampuan pemecahan masalah matematika, untuk mengukur sejauh mana tingkat kemampuan pemecahan masalah matematika mahasiswa sebelum dan sesudah penggunaan media.

Lembar validasi dan angket tanggapan mahasiswa menggunakan skala Likert. Data yang telah diperoleh dari angket selanjutnya dianalisis dengan frekuensi jawaban tiap alternatif yang dipilih responden dikalikan 100\%. Hasil persentase kelayakan dikonversi kedalam kategori atau kriteria kelayakan berdasarkan Tabel 1 (Mahuda, Suhamah, Nasrullah, \& Junedi, 2020).

Adapun hasil pretest dan posttest untuk mengukur peningkatan kemam-puan pemecahan masalah sebelum dan sesudah penggunaan media pembelajaran yang dikembangkan dianalisis dengan menggunakan normalitas gain $(N$-gain) dan analisis statistik uji paired-sample t-test. Perhitungan normalitas gain ( $N$-gain) menggunakan rumus (1) (Nurhairunnisah \& Sujarwo, 2018).

$$
\text { Ngain }=\frac{\text { S Post }- \text { S Pre }}{\text { S maks }- \text { S Pre }}
$$


DOI: https://doi.org/10.24127/ajpm.v10i3.3912

Tabel 1. Tingkat penilaian dan kualifikasi penilaian

\begin{tabular}{cccc}
\hline Persentase & \multicolumn{2}{c}{ Kriteria Kelayakan } & \multirow{2}{*}{ Ket. } \\
\cline { 2 - 3 } Kelayakan & Kevalidan & Kepraktisan & \\
\hline$P \leq 20$ & Tidak Valid & Tidak Praktis & Revisi \\
$20<P \leq 40$ & Kurang Valid & Kurang Praktis & Revisi \\
$40<P \leq 60$ & Cukup Valid & Cukup Praktis & Revisi Kecil \\
$60<P \leq 80$ & Valid & Praktis & Tidak Perlu Revisi \\
$P \geq 80$ & Sangat Valid & Sangat Praktis & Tidak Perlu Revisi \\
\hline
\end{tabular}

Tabel 2. Kriteria nilai $N$-gain

\begin{tabular}{cc}
\hline Rentang Nilai & Kriteria \\
\hline$N$-gain $>0,7$ & Tinggi \\
$0,3 \leq N$-gain $\leq 0,7$ & Sedang \\
$N$-gain $<0,3$ & Rendah \\
\hline
\end{tabular}

Keterangan:

$N$-gain = normalitas gain

$\mathrm{S}$ post $=$ rata-rata skor posttest

$\mathrm{S}$ pre $=$ rata-rata skor pretest

$\mathrm{S}$ maks= skor maksimal

Nilai $N$-gain yang diperoleh kemudian diinterpretasikan sesuai dengan Tabel 2.

\section{HASIL DAN PEMBAHASAN}

Model yang digunakan dalam penelitian dan pengembangan ini adalah model ADDIE yang terdiri dari 5 (lima) tahapan yaitu Analysis, Design, Development, Implementation, dan Evaluation. Adapun uraian hasil dari kelima tahapan tesebut adalah sebagai berikut:

\section{A. Tahapan Analysis}

Berdasarkan hasil observasi yang peneliti lakukan terhadap pembelajaran daring yang telah berlangsung pada mata kuliah Matematika Ekonomi di Jurusan Manajemen Fakultas Ekonomi dan Bisnis Universitas Bina Bangsa Tahun Akademik 2020/2021, lebih banyak mahasiswa yang memilih memanfaatkan perangkat smartphone berbasis android dibanding perangkat lainnya. Hal ini menjukan bahwa pengembangan media pembelajaran berbasis android sangat tepat untuk diterapkan dalam pembelajaran daring saat ini. Disamping itu, sejalan dengan pendapat yang diutarakan oleh (Muyaroah \& Fajartia, 2017) yang menyatakan bahwa media pembelajaran berbasis android memiliki beberapa kelebihan yaitu media ini memiliki tampilan desain yang menarik, baik dari segi warna, tulisan, gambar dan animasi. Media ini mudah dioperasikan, dipahami dan mudah dimengerti oleh peserta didik pengguna.

Pemilihan aplikasi Smart Apps Creator dikarenakan aplikasi ini sangat user-friendly, mudah digunakan dan tidak membutuhkan bahasa pemrograman yang rumit. Selanjutnya, analisis kurikulum yang dilakukan untuk mengkaji kurikulum agar media pembelajaran yang dikembangkan sesuai dengan kurikulum yang berlaku. Berdasarkan kurikulum yang berlaku di Jurusan Manajemen Fakultas Ekonomi dan Bisnis di salah satu perguruan tingi di Banten, capaian pembelajaran pada matakuliah Matematika Ekonomi yaitu mahasiswa dapat menjelaskan konsepkonsep matematika dan penerapannya dalam ekonomi dan bisnis. Konsep matematika tersebut diantaranya yaitu optimasi fungsi, kalkulus integral, aljabar matriks dan program linier. Dari hasil analisis kurikulum, dilakukan analisis materi untuk menentukan materi yang akan dipelajari dalam pembelajaran menggunakan media yang dikembangkan. Peneliti memilih satu topik materi yang berjudul "Matriks dan Aplikasinya dalam Ekonomi dan Bisnis". 


\section{B. Tahapan Design}

Pada tahapan ini dihasilkan suatu produk awal (prototype) atau rancangan produk yang disesuaikan dengan analisis yang telah dilakukan. Pemilihan materi dengan topik bahasan Matriks dan Aplikasinya dalam Ekonomi dan Bisnis disusun berdasarkan referensi dari beberapa sumber buku Matematika Ekonomi. Pada topik ini dibagi menjadi 4 (empat) subttopik dimana setiap satu subtopik untuk satu pertemuan. Adapun 4 (empat) subtopik tersebut diantaranya yaitu: konsep dasar matriks, determinan matriks, invers matriks dan sistem persamaan linier dengan matriks beserta aplikasinya dalam ekonomi-bisnis. Pada tahapan ini peneliti mulai men-download aplikasi Smart Apps Creator versi 3.0 dan mulai merancang tampilan layout menggunakan Canva untuk startpage (halaman muka) dan menu-menu yang tersedia pada media. Selain itu, peneliti juga mulai mengumpulkan asset-aset seperti gambar, musik pengiring, serta video untuk keperluan dalam pembuatan button (tombol), backsong dan kelengkapan materi. Adapun untuk instrument penilaian yaitu berupa pretes dan postes (evaluasi) disusun berdasarkan indikator kemampuan pemecahan masalah matematika.

\section{Tahapan Development}

Pada tahapan development merupakan mengembangkan rancangan kerangka media pembelajaran dan instrumen yang dibuat pada tahap sebelumnya. Produk yang dikembangkan dalam penelitian ini yaitu berupa media pembelajaran matematika dalam bentuk modul yang diberi nama "MoDIf" merupakan singkatan dari "Modul Digital Interaktif" yang berisi materi dengan topik bahasan Matriks dalam Mata Kuliah Matematika
Ekonomi. Berikut adalah gambar halaman muka (start page) yang juga dijadikan icon aplikasi "MoDIf" (Gambar 1).

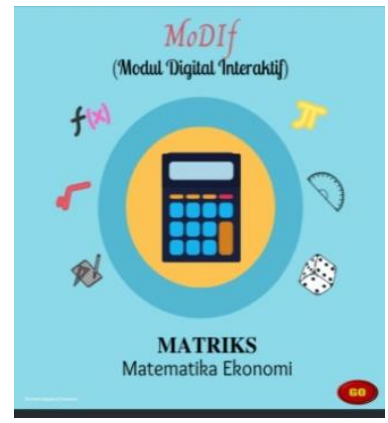

Gambar 1. Start page dan icon aplikasi

Beberapa menu yang tersedia dalam aplikasi MoDIf ini diantaranya yaitu menu petunjuk penggunaan, pretes, materi, evaluasi, dan tentang produk. Berikut adalah gambar halaman yang memuat beberapa menu dalam aplikasi (Gambar 2).

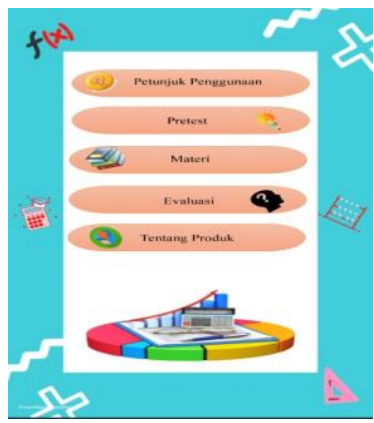

Gambar 2. Halaman Menu Aplikasi

Adapun contoh tampilan materi yang dalam aplikasi Modif (Gambar 3).

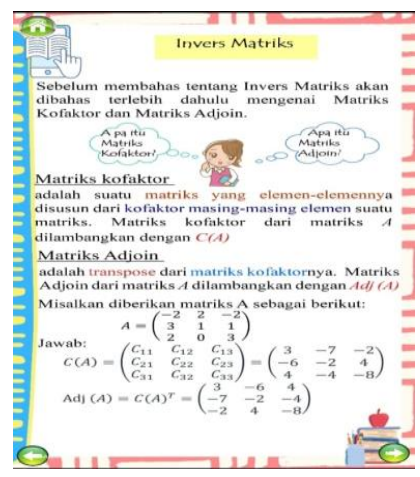

Gambar 3. Contoh materi dalam aplikasi 
DOI: https://doi.org/10.24127/ajpm.v10i3.3912

Selain itu, di beberapa materi yang membutuhkan penjelasan lebih rinci, peneliti menginsert link video Youtube. Contohnya dalam materi operasi matriks (Gambar 4).

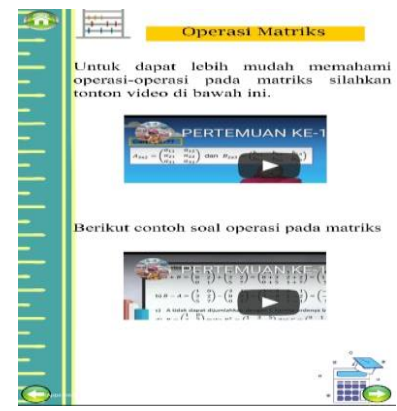

Gambar 4. Insert Video Youtube

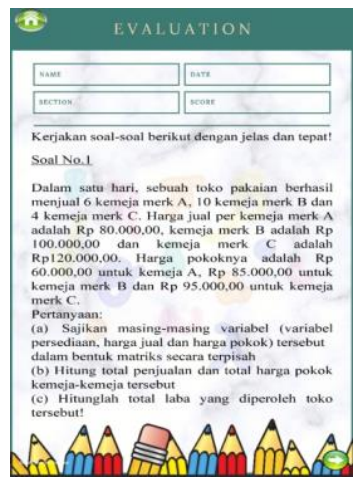

Gambar 5. Soal evaluasi dalam aplikasi

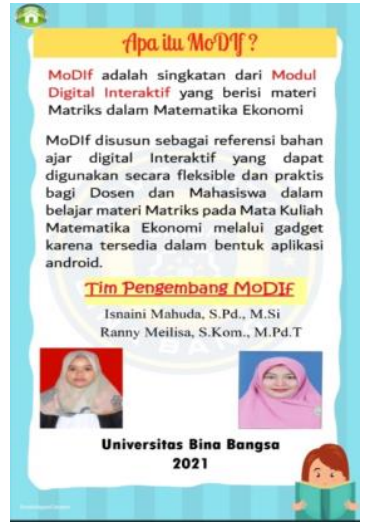

Gambar 6. Tentang produk

Pada bagian akhir terdapat evaluasi yang memuat soal-soal tes kemampuan pemecahan matematis serta tentang produk yang memuat identitas produk dan tim pengembang (Gambar 5 dan 6).
Setelah produk dikembangkan selanjutnya divalidasi oleh para ahli yang terdiri dari ahli materi dan ahli media. Validasi dilakukan dalam bentuk penilaian melalui lembar validasi yang memuat beberapa indikator. Validasi materi dilakukan oleh dosen matematika dan dosen pendidikan matematika sedangkan validasi media dilakukan oleh dosen pendidikan matematika dan dosen pendidikan teknologi informasi. Dari hasil penilaian dari para ahli diperoleh rekapitulasi hasil penilaian (Tabel 3).

Tabel. 3 Rekapitulasi hasil penilaian para ahli

\begin{tabular}{cccl}
\hline No & Validator & $\begin{array}{c}\text { Persen- } \\
\text { tase }\end{array}$ & Kriteria \\
\hline 1 & Ahli Materi & $81 \%$ & Sangat Valid \\
2 & Ahli Media & $94,16 \%$ & Sangat Valid \\
\hline & Rata-rata & $87,58 \%$ & Sangat Valid \\
\hline
\end{tabular}

Berdasarkan Tabel 3 menunjukkan bahwa hasil penilaian dari para ahli baik itu dari ahli materi maupun dari ahli media berada pada kriteria sangat valid. Dengan demikian, produk yang dikembangkan layak untuk digunakan tanpa revisi. Namun ada beberapa komentar, saran/masukan dari para ahli guna memperbaiki kualitas produk yang dikembangkan. Adapun saran/masukan dari ahli materi yaitu agar menambahkan contoh-contoh soal yang lebih bervariatif dan aplikatif dalam modul sehingga kemampuan berfikir mahasiswa dapat lebih terasah. Sedangkan saran/masukan dari ahli media yaitu untuk animasi icon terlalu kaku mungkin bisa di perbaiki atau dirubah menjadi animasi yang lain, agar tidak terlalu monoton. Adapun komentar dari ahli media yang lainnya menyatakan bahwa aplikasi ini sudah sangat cukup baik. 


\section{Tahapan Implementation}

Setelah produk yang dikembangkan divalidasi oleh para ahli materi dan media serta dinyatakan sangat valid dan layak digunakan tanpa revisi maka selanjutnya produk diujicobakan kepada subyek penelitian dalam skala kecil. Pada tahapan ini dilakukan pula pretestposttest untuk mengukur keefektifan peningkatan ke-mampuan pemecahan masalah sebelum dan sesudah penggunaan produk.

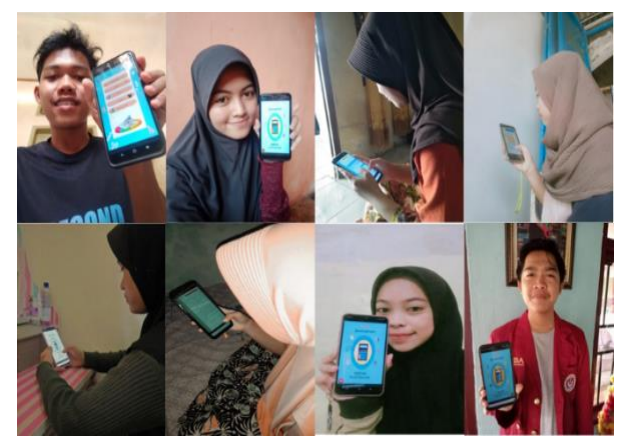

Gambar 7. Ujicoba Produk kepada Subyek Penelitian

Produk yang telah dikembangkan berekstensi .apk kemudian disimpan kedalam google drive dan link akses dishare kepada subjek penelitian untuk didowload dan diinstal ke smartphone masing-masing (Gambar 7).

Setelah ujicoba produk kepada subyek penelitian selanjutnya dilakukan pengukuran terhadap tingkat kepraktisan produk yang dikembangkan melalui penilaian lembar angket respon mahasiswa. Adapun rekapitulasi penilaian respon mahasiswa terhadap tingkat kepraktisan produk yang dikembangkan disajikan dalam Tabel 4.

Berdasarkan tabel 4 diperoleh rata-rata presentase penilaian respon mahasiswa sebesar 88,08\% sehingga tingkat kepraktisan produk termasuk dalam kritera sangat praktis. Sangat praktis digunakan yaitu dapat digunakan kapan saja dan dimana saja.
Tabel. 4 Rekapitulasi penilaian respon mahasiswa terhadap tingkat kepraktisan produk

\begin{tabular}{cccl}
\hline No & Aspek & Persentase & Kriteria \\
\hline 1 & Media & $89,14 \%$ & Sangat Praktis \\
2 & Materi & $89,31 \%$ & Sangat Praktis \\
3 & Manfaat & $85,81 \%$ & Sangat Praktis \\
\hline Rata-rata & $88,08 \%$ & Sangat Praktis \\
\hline
\end{tabular}

Bagian akhir pada tahapan ini yaitu melakukan uji efektivitas penggunaan produk dalam meningkatkan kemampuan pemecahan masalah matematika mahasiswa yang dilakukan melalui analisis data hasil pretestpostest. Pretest-postest menggunakan instru-ment tes tertulis dalam bentuk essay yang disusun berdasarkan indikator kemampuan pemecahan masalah matematika setelah dilakukan validitas dan reabilitas sebelum instrument tes digunakan. Data hasil pretest-postest ini dianalisis menggunakan normalitas gain (N-gain) dan analis statistik dengan uji paired sampel t-test berbantuan software IBM SPSS versi 25. Berdasarkan analisis normalitas gain (N-gain) diperoleh hasil, yaitu:

$\mathrm{N}$-gain $=\frac{S \text { Pos }-S \text { Pre }}{S \text { maks }-S \text { Pre }}$

$\mathrm{N}$-gain $=\frac{79-48}{100-48}$

$\mathrm{N}$-gain $=0,6$

Berdasarkan perhitungan diperoleh normalitas gain ( $\mathrm{N}$-gain) sebesar 0,6 dan termasuk kriteria sedang. Selanjutnya analisis statistic uji paired sample t-test digunakan untuk mengetahui apakah ada perbedaan yang signifikan antara kemampuan pemecahan masalah matematika mahasiswa sebelum dan setelah penggunaan produk yang dikembangkan yaitu media pembelajaran berbasis android berbantuan Smart Apps Creator. Syarat untuk melakukan uji 
DOI: https://doi.org/10.24127/ajpm.v10i3.3912

paired sample t-test adalah data yang digunakan harus berdistribusi normal.

Dalam penelitian telah dilakukan pengujian normalitas dan homogenistas. Langkah berikutnya dilakukan uji paired sample t-test yang hasilnya disajikan pada Tabel 5.

Tabel. 5 Hasil Uji Paired Sample T-Test

\begin{tabular}{llcrr}
\hline & t & df & $\begin{array}{l}\text { Sig. (2- } \\
\text { tailed) }\end{array}$ \\
\hline Pair 1 & $\begin{array}{l}\text { Pretest }- \\
\text { Postest }\end{array}$ & -15.784 & 3 & .000 \\
& & 4 & \\
\hline
\end{tabular}

Hipotesis:

$\boldsymbol{H}_{\mathbf{0}}$ : Tidak terdapat perbedaaan yang signifikan antara hasil pretest dan posttest kemampuan pemecahan masalah matematika.

$\boldsymbol{H}_{\boldsymbol{a}}$ : Terdapat perbedaaan yang signifikan antara hasil pretest dan posttest kemampuan pemecahan masalah matematika.

Kriteria pengujian:

1) Terima $H_{0}$ jika sig. $>0,05$

2) Tolak $H_{0}$ jika sig. $<0,05$

Berdasarkan tabel 6 diperoleh nilai Sig. (2-tailed) dengan $\alpha=0.05$ sebesar 0.000 sehingga Sig. $<0.05$, dengan demikian dapat disimpulkan bahwa $H_{0}$ ditolak dan $H_{a}$ diterima yang artinya terdapat perbedaan yang signifikan antara hasil pretest dan postest kemampuan pemecahan masalah matematika mahasiswa. Hasil ini mengindikasikan bahwa penggunaan media pembelajaran matematika berbasis android berbantuan Smart Apps Creator efektif dalam meningkatkan kemampuan pemecahan masalah matematika mahasiswa.

\section{E. Tahapan Evaluation}

Berdasarkan analisis data hasil penilaian para ahli materi dan media diperoleh kesimpulan bahwa produk yang dikembangkan layak digunakan tanpa perlu revisi namun dengan mempertimbangkan saran dan masukan yang diberikan oleh ahli materi dan ahli media maka peneliti melakukan tindak lanjut dilakukan perbaikan. Berikut merupakan saran yang diberikan oleh ahli materi dan ahli media (Tabel 6).

Tabel. 6 Saran dari ahli materi dan media

\begin{tabular}{cll}
\hline No. & $\begin{array}{c}\text { Saran } \\
\text { Perbaikan }\end{array}$ & Tindak Lanjut \\
\hline 1. & Dari Ahli & Menambahkan \\
& Materi: & contoh soal yang \\
& Contoh soal & lebih variatif dan \\
kurang & aplikatif di \\
& variatif dan & Bidang Ekonomi- \\
& aplikatif & Bisnis \\
2. & Dari Ahli & Merubah dan \\
& Media: & menambah \\
& Animasi & animasi icon agar \\
& icon terlalu & tidak terlalu kaku \\
& kaku dan & dan monoton \\
& monoton & \\
\hline
\end{tabular}

Produk akhir dari pengembangan media pembelajaran ini berupa modul matematika yang diberi nama "MoDIf" Modul Digital Interaktif) untuk Materi matriks dalam mata kuliah matematika ekonomi. Media ini berbentuk file ekstensi aplikasi yang bisa di install di semua smartphone berbasis android. Media ini dapat dikatakan sebagai produk jadi dan dapat digunakan dalam pembelajaran matematika.

Berdasarkan hasil penelitian menunjukkan bahwa media pembelajaran berbasis android berbantuan Smart Apps Creator dapat dimanfaatkan dalam meningkatkan kualitas proses pembelajaran daring yang berlangsung saat ini akibat pandemi Covid-19. Hal ini sejalan dengan hasil penelitian (Khoirudin, Ashadi, \& Masykuri, 2021) yang menyatakan bahwa "the implementation of the mobile learning model 
using the Smart Apps Creator 3 application is effective to improve student learning outcomes during the pandemic of Covid-19". Sejalan dengan itu, dalam penelitian (Widiastika, Hendracipta, \& Syachruroji, 2021) menyatakan bahwa pengembangan media pembelajaran berbasis android dengan menggunakan software Smart App Creator sebagai software pengembang utama yang menunjukkan hasil positif terhadap kemampuan pemahaman konsep anak didik.

Kelebihan penelitian menggunakan SmartApps Creator adalah: a) aplikasi yang tidak memerlukan keahlian pemrograman untuk berfungsi sebagai media pembelajaran; b) tampilan mudah dipahami, memungkinkan guru dan mahasiswa berkomunikasi secara efektif (komunikasi visual); c) menjadi aplikasi pedoman proses pembelajaran dengan akses sederhana melalui ponsel, PC, dan laptop. Hal ini sejalan dengan hasil penelitian yang menyatakan bahwa SmartApps Creator mudah digunakan untuk proses belajar mengajar baik perorangan maupun kelompok (Azizah, 2020).

Kekurangan penelitian menggunakan SmartApps Creator adalah: a) pengembangan media pembelajaran hanya gratis selama 30 hari, oleh karena itu pengguna harus menginstal ulang atau membayar; b) jika pengembangan awal menggunakan pengaturan smartphone resolusi tinggi, aplikasi akan sulit digunakan ketika dikurangi menjadi resolusi yang lebih rendah.

Hasil penelitian ini sejalan yang menyatakan bahwa perencanaan media pembelajaran harus disesuaikan dengan kondisi peserta didik dan harus membangun berinteraksi dalam dua cara dengan memasukkan berbagai kualitas yang dimiliki guru (Yuberti, Wardhani, \& Latifah, 2021).
Dampak dari hasil penelitian menunjukkan bahwa penggunaan media pembelajaran matematika berbasis android berbantuan Smart Apps Creator meningkatkan kemampuan pemecahan masalah matematis mahasiswa. Hal ini disebabkan karena dalam media tersebut telah memadukan beberapa unsur seperti video, audio, gambar dan tulisan yang membuat belajar matematika menjadi rileks sehingga meningkatkan pengalaman, pemahaman, minat dan perhatian mahasiswa terhadap materi (Chang et al., 2017).

Dengan demikian hasil penelitian menunjukan bahwa dapat menstimulus dan mengoptimalkan kemampuan pemecahan masalah matematis mahasiswa. Hasil ini sejalan dengan penelitian media pembelajaran berbasis android dapat meningkatkan kemampuan pemecahan masalah (Fatma \& Partana, 2019).

Implikasi media pembelajaran matematika berbasis android sudah selayaknya terus dikembangkan mengingat perkembangan ilmu pengetahuan dan teknologi (IPTEK) yang juga semakin cepat terutama disituasi pandemi Covid-19 dimana semua kegiatan belajar mengajar dilakukan secara daring di rumah. Dengan adanya media pembelajaran seperti ini proses penyampaian materi tidak menjadi monoton dan tetap sesuai dengan perkembangan zaman.

Media pembelajaran berbasis android berbantuan software Smart Apps Creator ini dapat dikembangkan oleh para guru ataupun dosen karena software ini mudah dioperasikan dan tidak memerlukan bahasa pemrograman yang rumit. Selain itu, dengan media ini peserta didik dapat belajar dimana saja dan kapan saja melalui smartphone berbasis android. 
Terlebih pengguna smartphone berbasis android saat ini sangat tinggi khususnya di usia remaja dan mahasiswa. Mahasiswa lebih cenderung memilih membuka gadget dibanding buku teks konvensional untuk mencari referensi materi perkuliahan.

Dengan demikian, pengembangan media pembelajaran berbasis android berbantuan Smart Apps Creator ini membuat mahasiswa dapat belajar hanya dengan membuka smartphone mereka tanpa harus mencari referensi melalui buku teks konvesional.

\section{KESIMPULAN DAN SARAN}

Berdasarkan hasil penelitian dan pembahasan maka dapat diperoleh kesimpulan bahwa: 1) media pembelajaran matematika berbasis android berbantuan Smart Apps Creator yang telah dikembangkan berada pada kriteria sangat validitas dan layak untuk digunakan menurut penilaian para ahli materi dan media; 2) Respon mahasiswa terhadap penggunaan media pembelajaran matematika berbasis android berbantuan Smart Apps Creator menunjukan bahwa media ini berada pada kriteria sangat praktis dari segi media, materi dan manfaat; 3) Hasil uji keefektifan dengan menganalisis skor pretest-posttest menunjukkan media pembelajaran matematika berbasis android berbantuan Smart Apps Creator efektif meningkatkan kemampuan pemecahan masalah matematis siswa.

Saran untuk penelitian selanjutnya dapat mengembangkan media pembelajaran matematika berbasis android berbantuan Smart Apps Creator untuk materi-materi lainnya atau bahkan untuk mata kuliah matematika lainnya serta merancang dengan design dan isi yang lebih menarik sehingga dapat menjadi referensi bagi mahasiswa dalam belajar di masa pandemi (secara daring).

\section{DAFTAR PUSTAKA}

Azizah, A. R. (2020). Penggunaan Smart Apps Creator ( SAC ) untuk Mengajarkan Global Warming. Seminar Nasional Fisika (SNF), 72-80. Surabaya: Universitas Negeri Surabaya.

Budyastomo, A. W. (2020). Gim Edukasional untuk Pengenalan Tata Surya Educational Game for Basic Knowledge of Solar System. Teknologi: Jurnal Ilmiah Sistem Informasi, 10(2), 55-66. Retrieved from https://doi.org/10.26594/teknologi .v10i2.1955

Chang, C.-C., Liang, C., Chou, P.-N., \& Lin, G. Y. (2017). Is Game-Based Learning Better in Flow Experience and Various Types of Cognitive Load Than Non-GameBased Learning? Perspektive from Multimedia and Media Richness. Computers in Human Behavior, 71, 218-227. Retrieved from https://doi.org/10.1016/j.chb.2017 .01 .031

Dasmo, Astuti, I. A. D., \& Nurullaeli. (2017). Pengembangan Pocket Mobile Learning Berbasis Android. JRKPF UAD, 4(2), 7177.

Fatma, A. D., \& Partana, C. F. (2019). Pembelajaran Berbantu Aplikasi Android untuk Meningkatkan Kemampuan Pemecahan Masalah Kimia. Jurnal Inovasi Pendidikan IPA, 5(2), 229-236. Retrieved from https://doi.org/10.21831/jipi.v5i2. 26035

Khoirudin, R., Ashadi, \& Masykuri, M. (2021). Smart Apps Creator 3 to Improve Student Learning Outcomes During the Pandemic of COVID-19. JPBI (Jurnal 
DOI: https://doi.org/10.24127/ajpm.v10i3.3912

Pendidikan Biologi Indonesia), 7(1), 25-34. Retrieved from https://doi.org/10.22219/jpbi.v7i1. 13993

Mahuda, I., Suhamah, A., Nasrullah, A., \& Junedi, B. (2020). Pengembangan Bahan Ajar Mateamtika Ekonomi Berbasis VLog Berorientasi pada Kemampuan Penguasaan Konsep dan Komunikasi Matematis. AKSIOMA: Jurnal Program Studi Pendidikan Matematika, 9(3), 516-529.

Muyaroah, S., \& Fajartia, M. (2017). Pengembangan Media Pembelajaran Berbasis Android dengan menggunakan Aplikasi Adobe Flash CS 6 pada Mata Pelajaran Biologi. Innovation Journal of Curriculum and Educational Technology, 6(2301), 79-83.

Nurhairunnisah, \& Sujarwo. (2018). Bahan Ajar Interaktif untuk Meningkatkan Pemahaman Konsep Matematika pada Siswa SMA Kelas X. Jurnal Inovasi Teknologi Pendidikan, 5(2), 192203. Retrieved from http://dx.doi.org/10.21831/jitp.v5i 2.15320

Putra, E. A., Sudiana, R., \& Pamungkas, A. S. (2020). Pengembangan Smartphone Learning Management System ( S-LMS ) Sebagai Media Pembelajaran Matematika di SMA. KREANO: Jurnal Matematika Kreatif -Inovatif, 11(1), 36-45. Retrieved from http://dx.doi.org/10.15294/kreano. v11i1.21014

Qurohman, M. T., Sungkar, M. S., \& Abidin, T. (2019). DEVELOPMENT OF MATHEMATICS LEARNING
APPLICATION BASED ON ANDROID. Jurnal Pedagogik, 06(02), 475-513. Retrieved from https://ejournl.unuja.ac.id/index.p $\mathrm{hp} /$ pedagogik

Robianto, A., Wahono, \& Marsono. (2019). Pengembangan Modul Berbasis Aplikasi Android untuk Mata Kuliah Ilmu Bahan Teknik pada Prodi D3 Teknik Mesin Universitas Negeri Malang. Jurnal Teknik Mesin Dan Pembelajaran, 2(2), 124-133. Retrieved from http://journal2.um.ac.id/index.php /jtmp

Suhartati, O. (2021). Flipped Classroom Learning Based on Android Smart Apps Creator ( SAC ) in Elementary Schools. J.Phys.:Conf.Ser. https://doi.org/10.1088/17426596/1823/1/012070

Widiastika, M. A., Hendracipta, N., \& Syachruroji, A. (2021). Pengembangan Media Pembelajaran Mobile Learning Berbasis Android pada Konsep Sistem Peredaran Darah di Sekolah Dasar. Jurnal Basicedu, 5(1), 47-64. Retrieved from https://doi.org/10.31004/basicedu. v5i1.602

Yuberti, Wardhani, D. K., \& Latifah, S. (2021). Pengembangan Mobile Learning Berbasis Smart Apps Creator Sebagai Media Pembelajaran Fisika. Physics and Science Education (PSEJ), 1(2), 90-95. 